\title{
Suppressing N-Acetyl-L-Aspartate Synthesis Prevents Loss of Neurons in a Murine Model of Canavan Leukodystrophy
}

\author{
Jiho Sohn, ${ }^{1 \star}$ Peter Bannerman, ${ }^{1 \star}$ () Fuzheng Guo, ${ }^{1 \star}$ Travis Burns, ${ }^{1}$ Laird Miers, ${ }^{1}$ Christopher Croteau, ${ }^{1}$ \\ Naveen K. Singhal, ${ }^{2}$ Jennifer A. McDonough, ${ }^{2}$ and $\odot$ David Pleasure ${ }^{1}$ \\ ${ }^{1}$ Institute for Pediatric Regenerative Medicine, University of California, Davis, Sacramento, California 95817, and ${ }^{2}$ Department of Biological Sciences and \\ School of Biomedical Sciences, Kent State University, Kent, Ohio 44242
}

Canavan disease is a leukodystrophy caused by aspartoacylase (ASPA) deficiency. The lack of functional ASPA, an enzyme enriched in oligodendroglia that cleaves $N$-acetyl-L-aspartate (NAA) to acetate and L-aspartic acid, elevates brain NAA and causes "spongiform" vacuolation of superficial brain white matter and neighboring gray matter. In children with Canavan disease, neuroimaging shows early-onset dysmyelination and progressive brain atrophy. Neuron loss has been documented at autopsy in some cases. Prior studies have shown that mice homozygous for the Aspa nonsense mutation Nur7 also develop brain vacuolation. We now report that numbers of cerebral cortical and cerebellar neurons are decreased and that cerebral cortex progressively thins in $A s p a^{\mathrm{Nur} / \mathrm{Nur} 7}$ mice. This neuronal pathology is prevented by constitutive disruption of $N a t 8 l$, which encodes the neuronal NAA-synthetic enzyme $N$-acetyltransferase-8-like.

Key words: aspartoacylase; Canavan disease; myelin; $\mathrm{N}$-acetyl-L-aspartate; $\mathrm{N}$-acetyltransferase-8-like; neuron

\section{Significance Statement}

This is the first demonstration of cortical and cerebellar neuron depletion and progressive cerebral cortical thinning in an animal model of Canavan disease. Genetic suppression of $\mathrm{N}$-acetyl-L-aspartate (NAA) synthesis, previously shown to block brain vacuolation in aspartoacylase-deficient mice, also prevents neuron loss and cerebral cortical atrophy in these mice. These results suggest that lowering the concentration of NAA in the brains of children with Canavan disease would prevent or slow progression of neurological deficits.

\section{Introduction}

Genetic screening for pathogenic aspartoacylase (ASPA) mutations has decreased the incidence of Canavan disease in Ashkenazi Jews, in whom $\sim 1$ in 60 is an asymptomatic heterozygous mutation carrier (Feigenbaum et al., 2004). Pathogenic ASPA mutations also occur, although less frequently, in other human populations (Kaul et al., 1994; Shaag et al., 1995). No therapies are yet available to prevent or reverse cognitive and motor deficits in children with this fatal leukodystrophy.

ASPA is expressed by mature oligodendroglia and serves to cleave $N$-acetyl-L-aspartate (NAA), releasing acetate that can be

\footnotetext{
Received June 23, 2016; revised Nov. 7, 2016; accepted Nov. 29, 2016.

Author contributions: J.S., P.B., F.G., and D.P. designed research;J.S., P.B., F.G., T.B., L.M., C.C., N.K.S., J.A.M., and D.P. performed research; J.S., P.B., F.G., T.B., L.M., C.C., N.K.S., J.A.M., and D.P. analyzed data; J.S., P.B., F.G., and D.P. wrote the paper.

This work was supported by NIH Grant R21NS096004, National Multiple Sclerosis Society Grant RG 5252-A-6, and the Shriners Hospitals for Children.

*J.S., P.B., and F.G. are co-first authors.

The authors declare no competing financial interests.

Correspondence should be addressed to Dr. David Pleasure, Department of Neurology, University of California Davis, c/0 Shriners Hospital, 2425 Stockton Boulevard, Sacramento, CA 95817. E-mail: depleasure@ucdavis.edu. DOI:10.1523/JNEUROSCI.2013-16.2016

Copyright $\odot 2017$ the authors $\quad 0270-6474 / 17 / 370413-09 \$ 15.00 / 0$
}

used for myelin lipid synthesis (Burri et al., 1991; Chakraborty et al., 2001; Francis et al., 2011, 2016; Bakken et al., 2016; Jolly et al., 2016). The lack of functional ASPA blocks NAA catabolism and elevates the brain NAA concentration $\left(\left[\mathrm{NAA}_{\mathrm{B}}\right]\right)$. This pathognomonic increase in $\left[\mathrm{NAA}_{\mathrm{B}}\right]$ can be detected by in vivo brain proton nuclear magnetic resonance spectroscopy (Janson et al., 2006b; Francis et al., 2012). Macrocephaly often develops during the first year after birth in Canavan disease (Traeger and Rapin, 1998), likely as a consequence of the onset of brain spongiform vacuolation during infancy (Adachi et al., 1973; Mirimanoff, 1976; Janson et al., 2006b). Progressive lags in motor and cognitive development are often already evident in the first 6 months after birth but occasionally first appear only later in childhood (Jellinger and Seitelberger, 1969; Janson et al., 2006a).

Astroglia express Nadc3 (encoded by Slc13a3), an $\mathrm{Na}^{+}$coupled dicarboxylate transporter with high affinity for NAA, and deploy NAA as an osmolyte to assist in maintaining CNS water homeostasis (Yodoya et al., 2006; Baslow and Guilfoyle, 2013; Clarner et al., 2014). The substantial increase in $\left[\mathrm{NAA}_{\mathrm{B}}\right]$ in Canavan disease may perturb this homeostatic mechanism. This perturbation has been hypothesized to cause the astroglial swelling and myelin lamellar splitting in brain superficial white matter 
and neighboring gray matter in this disorder (Gambetti et al., 1969; Mirimanoff, 1976; Fujita et al., 2005; Traka et al., 2008; Baslow and Guilfoyle, 2013; Clarner et al., 2014; Guo et al., 2015; Maier et al., 2015). A prediction of this hypothesis was that blocking NAA synthesis in the ASPA-deficient brain would prevent astroglial swelling and dysmyelination. To test this prediction, we bred mice homozygous for both an Aspa nonsense mutation $\left(\right.$ Aspa $a^{\text {Nur7/Nur7 }}$ ) (Traka et al., 2008) and for deletion of Nat8l (Nat81 ${ }^{-1-}$ ), the gene that encodes $N$-acetyltransferase-8-like (also known as aspartate $N$-acetyltransferase), a neuron-enriched enzyme essential for brain NAA synthesis (Ariyannur et al., 2010; Wiame et al., 2009; Wang et al., 2016). Whereas Aspa $a^{\mathrm{Nur} 7 / \mathrm{Nur} 7} / \mathrm{Nat} \mathrm{l}^{+/+}$mice, in which $\left[\mathrm{NAA}_{\mathrm{B}}\right]$ was markedly elevated, developed ataxia soon after weaning and, at autopsy, demonstrated brain vacuolation, $A s p a^{\text {Nur7/Nur7 }} / \mathrm{Nat} 8 l^{-1-}$ mice, in which $\left[\mathrm{NAA}_{\mathrm{B}}\right]$ was undetectably low, preserved normal motor function and did not develop brain vacuolation (Guo et al., 2015). These results were confirmed by another research group (Maier et al., 2015), which also reported that heterozygous constitutive Nat8l deletion in Aspa $a^{\text {Nur7/Nur7 }}$ mice partially prevented brain vacuolation.

Serial neuroimaging reveals progressive brain atrophy in children with Canavan disease (Janson et al., 2006b; Leone et al., 2012), and diminished numbers of forebrain and cerebellar neurons have been reported in some autopsied cases (Jellinger and Seitelberger, 1969; Adachi et al., 1973; Mirimanoff, 1976). We now demonstrate that constitutive disruption of $\mathrm{Nat} 8 \mathrm{l}$ prevents progressive cerebral cortical thinning and the loss of cerebral cortical, Purkinje, and internal granule neurons in $A s p a^{N u r 7 / N u r 7}$ mice.

\section{Materials and Methods}

Mice. Heterozygous $A s p a^{N u r 7}$ mice (Aspa $a^{\text {Nur7/+ }}$, C57BL/6J background; RRID:MGI:3027206) were from The Jackson Laboratory (stock number 008607), and heterozygous Nat8l knock-out mice (Nat8l ${ }^{+/-}, \mathrm{C} 57 \mathrm{BL} / 6 \mathrm{~J}$ background; RRID:IMSR_KOMP:VG11213-1-Vlcg; Guo et al., 2015) were from the University of California Davis (UC Davis) KOMP Repository (project ID VG11213). We bred these two mutant strains to produce Aspa ${ }^{+/ N u r 7} / \mathrm{Nat}^{+/ /-}$mice, which were then crossed to generate mice of the desired Aspa ${ }^{+/+} / \mathrm{Nat} \mathrm{I}^{+/+}, \mathrm{Aspa}^{\mathrm{Nur7} / \mathrm{Nur} 7} / \mathrm{Nat}^{+1 /+}$, Aspa $a^{\text {Nur7/Nur7 }} / \mathrm{Nat}^{+1 /-}$, and Aspa $a^{\text {Nur7/Nur7 }} / \mathrm{Nat}^{+} \mathrm{I}^{-/-}$genotypes, which were born in the predicted Mendelian ratios. Mixed groups of male and female mice were used in all studies reported here. All mouse protocols were approved by the UC Davis Institutional Animal Care and Use Committee (protocol number 18029).

Aspa Western blot and qRT-PCR for Nat8l, LacZ, and Cnp mRNAs. The anti-Aspa antibody used for the Western blot was from Proteintech (catalog \#13244-1-AP; RRID:AB_2274358). Primers for Nat8l mRNA were forward 5'-ATCTTCTACGACGGCATCTTGG-3' and reverse 5'-GCGGGTCACAGCAAAACAG-3'. Primers for lacZ mRNA, which was inserted into the Nat8l locus during VelociGene Nat8l disruption (Valenzuela et al., 2003), were forward 5'-CGCTGACGGAAGCAAAACA-3' and reverse 5'-GC CCGGATAAACGGAACTG-3'. Primers for 2', 3' -cyclic nucleotide 3-phosphodiesterase $(C n p)$ mRNA were forward $5^{\prime}$-TTTACCCGCAAAAG CCACACA- $3^{\prime}$ and reverse 5'-CACCGTGTCCTCATCTTGAAG-3'.

$\left[N A A_{B}\right]$ assay. Six-month-old mice were deeply anesthetized with ketamine/xylazine. Their brains (including forebrain, cerebellum, and upper brainstem) were flash-frozen and stored at $-70^{\circ} \mathrm{C}$. $\left[\mathrm{NAA}_{\mathrm{B}}\right]$ was measured by HPLC (Li et al., 2013). For this purpose, the brains were homogenized in ice-cold 90\% methanol and centrifuged twice at 14,000 $\mathrm{rpm}$ for $10 \mathrm{~min}$ at $4^{\circ} \mathrm{C}$. The supernatants were dried by speed-vac, dissolved in $0.5 \mathrm{ml}$ of deionized water, and applied to AG50W x- 8 poly-pre columns (Bio-Rad). The columns were then washed with $1 \mathrm{ml}$ of deionized water, and all eluates were collected, lyophilized, and stored at $4^{\circ} \mathrm{C}$. For HPLC analysis, the lyophilized eluates were resuspended in $300 \mu \mathrm{l}$ of deionized $\mathrm{H}_{2} \mathrm{O}$. Samples and NAA standards (Sigma-Aldrich) were applied to a Whatman Partisil 10 SAX anion-exchange column $(4.6 \times 250$ mm) using an Agilent 1100 Series HPLC value system (Agilent Technologies). The mobile phase consisted of $0.1 \mathrm{M} \mathrm{KH}_{2} \mathrm{PO}_{4}$ and $0.025 \mathrm{M} \mathrm{KCl}, \mathrm{pH}$ 4.5. After the column was washed with $50 \%$ acetonitrile and $50 \%$ deionized water, it was conditioned with 20-30 column volumes of new mobile phase. Retention data were collected at a flow rate of $1.5 \mathrm{ml} / \mathrm{min}$ and were monitored at $214 \mathrm{~nm}$ using an Agilent 1100 Series UV detector ( $\mathrm{Li}$ et al., 2013). Under these conditions, the NAA retention time was 5.10 min. Peak areas were ascertained with Agilent Chemstation software. $\left[\mathrm{NAA}_{\mathrm{B}}\right]$ was determined by reference to an NAA standard curve, measured in duplicate for each mouse, and normalized to whole-brain weight.

Rotarod testing. Motor function was assessed by measuring accelerating rotarod retention times at ages 2 and 12 months. The 12-month-old Aspa ${ }^{+/+} / \mathrm{Nat}^{+l^{+/+}}, \quad$ Aspa $a^{\text {Nur7/Nur7 }} / \mathrm{Nat}^{+/+} l^{++}$and Aspa $a^{\text {Nur7/Nur7 }} /$ $\mathrm{Nat} \mathrm{I}^{-/-}$mice used in these accelerating rotarod tests were identical to those previously tested by this means at age 2 months (Guo et al., 2015). An additional group of $A s p a^{\text {Nur7/Nur7 }} / \mathrm{Nat} \mathrm{I}^{+/-}$mice was also evaluated at 2 and 12 months of age. The rotarod starting speed was four rotations per minute (rpm), followed by a speed step of $1.3 \mathrm{rpm}$ every $10 \mathrm{~s}$. The mice were subjected to 5 min training sessions every day for $10 \mathrm{~d}$, at which point they had achieved plateau performances. These plateau retention times were used for statistical analysis.

Histology. Before laser-scanning confocal microscopy, 6-month-old mice were deeply anesthetized with ketamine/xylazine and perfused with $4 \%(\mathrm{w} / \mathrm{v})$ paraformaldehyde in PBS, pH 7.4. Their brains were harvested, postfixed in $4 \%$ paraformaldehyde in PBS overnight at $4^{\circ} \mathrm{C}$, washed in PBS, and embedded in OCT. Cryostat sections were air-dried at room temperature. The sections were then incubated in $8 \%$ normal donkey serum $(\mathrm{v} / \mathrm{v})$ and $0.1 \%$ Triton X-100 (v/v) in PBS, pH 7.4, for $1 \mathrm{~h}$ at room temperature, followed by incubation with one of the following primary antibodies overnight at $4^{\circ} \mathrm{C}$ in PBS containing 5\% normal donkey serum $(\mathrm{v} / \mathrm{v})$ and $0.1 \%$ Triton X-100 (v/v): mouse anti-calbindin IgG (1:1000 dilution, Swant 300; RRID:AB_10000347), rabbit anti-glial fibrillary acidic protein (GFAP) IgG (1:500 dilution, Dako Z033429-02; RRID: AB_10013482), mouse anti-NeuN IgG1 (1:500 dilution, Millipore MAB377; RRID:AB_2298772), rat anti-myelin basic protein (MBP) IgG2b (1:5 dilution, Millipore MAB395; RRID:AB_240845), or rabbit anti-cleaved caspase-3 IgG (1:200 dilution, Cell Signaling 9661; RRID: $\left.A B \_2341188\right)$. The sections were then incubated with Alexa Fluorconjugated donkey anti-mouse, anti-rabbit, or anti-rat secondary antibodies (IgG, 1:600 dilution, Invitrogen) for $1 \mathrm{~h}$ at room temperature and mounted in Prolong Gold containing DAPI (Invitrogen).

Coronal sections of forebrain at bregma $-1.1 \mathrm{~mm}$ were used for cerebral cortical thickness measurements and $\mathrm{NeuN}^{+}$neuron counts. To determine cerebral cortical thickness, NeuN-immunostained sections were imaged with a Nikon laser-scanning confocal microscope, and the images were processed using the NIS-Elements Annotations and Measurements tool. Ten vertical lines were drawn from the pial surface to the most dorsal NeuN ${ }^{+}$neuron in layer VI, and their lengths were averaged to calculate mean cortical thickness for each animal (Rattray et al., 2013). $\mathrm{NeuN}^{+}$neuron counts were performed on the same sections using an Olympus BX61-DSU microscope with motorized stage and StereoInvestigator software (Giannaris and Rosene, 2012). The optical dissector and guard zone were set at 8 and $2 \mu \mathrm{m}$, respectively. Twenty random $50 \times 50$ $\mu \mathrm{m}$ counting grids were assigned, and the $\mathrm{NeuN}^{+}$neuron counts were performed at $40 \times$ magnification.

Cerebella were sectioned from the midsagittal line through the vermis and imaged with a Nikon laser-scanning confocal microscope. The NISElements Annotate and Measure auto-detect function was used to evaluate vacuole area in cerebellar white matter by an observer blinded to genotype. Linear densities of calbindin ${ }^{+}$Purkinje neurons (Pinol et al., 1990) and the area occupied by $\mathrm{NeuN}^{+}$internal granule cells (Sarnat et al., 1998) were determined in cerebellar posterior lobes by an observer blinded to genotype, using NIH ImageJ software.

For transmission electron microscopy, 1-year-old mice were deeply anesthetized with ketamine/xylazine and perfused with $4 \%(\mathrm{w} / \mathrm{v})$ paraformaldehyde, followed by $3 \%(\mathrm{w} / \mathrm{v})$ glutaraldehyde, both in $0.1 \mathrm{~m}$ phosphate buffer, $\mathrm{pH}$ 7.4. Lateral sagittal cerebellar specimens (1-2 mm thick) were washed with $0.2 \mathrm{M}$ sodium cacodylate buffer, $\mathrm{pH}$ 
A

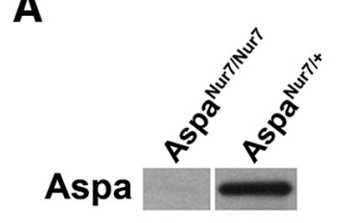

beta-actin

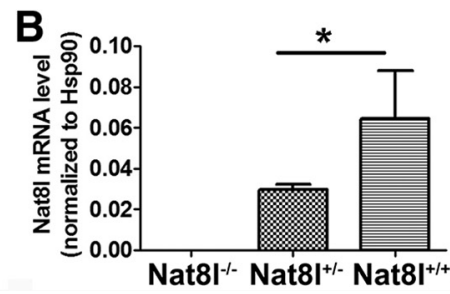

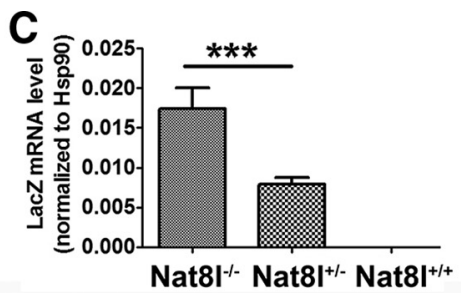

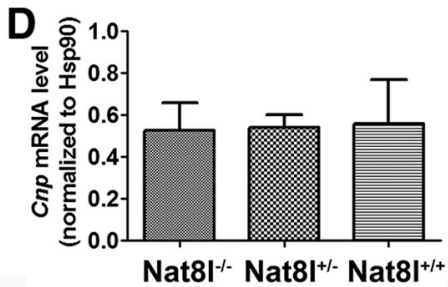

Figure 1. Biochemical characterization of $A s p a^{\text {Nur7/Nur7 }}$ and Nat8I $I^{-1-}$ mice. A, Western blot shows lack of detectable Aspa in an Aspa $a^{\text {Nur7/Nur7 }}$ mouse brain. B, qRT-PCR shows lack of Nat8I mRNA in Nat81 ${ }^{-1-}$ mouse brains. C, qRT-PCR shows presence of lacZ mRNA (inserted into the gene locus during Nat8/ disruption) (Valenzuela et al., 2003) in Nat81 ${ }^{-1-}$ mouse brains. D, qRT-PCR shows lack of effect of Nat8/ knock-out on mouse brain expression of Cnp mRNA, which encodes myelin CNPase. Results in $\boldsymbol{B}-\boldsymbol{D}$ are means of three mice per group. SEMs are indicated by vertical bars. ${ }^{*} p<0.05 ;{ }^{* * *} p<0.001$.

7.2 , postfixed in $2 \%(\mathrm{w} / \mathrm{v})$ aqueous osmium tetroxide for $2 \mathrm{~h}$, washed with cacodylate buffer, dehydrated through ascending alcohols, washed with propylene oxide, and embedded in EMBed-812 resin (Electron Microscopy Sciences). Ultrathin sections ( $70-80 \mathrm{~nm}$ ) were cut on a Leica EM UC7 microtome and collected on $1 \times 2 \mathrm{~mm}$ Formvar-coated copper slot grids, double stained with uranyl acetate and lead citrate, and examined on a CM120 electron microscope.

Statistical methods. The numbers of mice used for each study are shown in the figures as individual dots or are specified in the figure legends. Vertical bars denote SEs of the mean. Statistical analyses were by Student's $t$ test or by ANOVA followed by post hoc Tukey's multiple comparison test or Bonferroni's correction.

\section{Results}

Aspa $a^{\mathrm{Nur7/Nur7}}$ and $\mathrm{Nat8l}^{-/-}$mice

Aspa $a^{\text {Nur7/Nur7 }}$ mice did not express immunoreactive aspartoacylase (Fig. $1 \mathrm{~A}$ ). $\mathrm{Nat} 8 \mathrm{l}^{-/-}$mice, in which a lacZ reporter gene had been introduced during gene deletion (Valenzuela et al., 2003), did not express enough Nat8l mRNA for detection (Fig. 1B), but did express lacZ mRNA (Fig. 1C). Levels of mRNA encoding the myelin protein Cnp were not significantly different in $A s p a^{+/+}$/ $\mathrm{Nat} \mathrm{I}^{-/-}$and $\mathrm{Aspa}^{+/+} / \mathrm{Nat}^{+1 /-}$ mice than in wild-type $\left(\right.$ Aspa $\left.^{+/+} / \mathrm{Nat}^{+/+}\right)$mice (Fig. 1D).

Disrupting Nat8l lowers $\left[\mathrm{NAA}_{\mathrm{B}}\right]$ in $\mathrm{Aspa}^{\mathrm{Nur7/Nur7}}$ mice At age 6 months, mean $\left[\mathrm{NAA}_{\mathrm{B}}\right]$ was $5.8 \mathrm{~mm}$ in wild-type $\left(\mathrm{Aspa}^{+/+} / \mathrm{Nat}^{+l^{+/+}}\right)$mice, $7.6 \mathrm{mM}$ in $\mathrm{Aspa}^{\mathrm{Nur7} / \mathrm{Nur} 7} / \mathrm{Nat}^{+1 /-}$ mice, and $10.8 \mathrm{~mm}$ in $A s p a^{N u r 7 / N u r 7} / \mathrm{Nat} \mathrm{I}^{+/+}$mice (Fig. 2). NAA was not detectable in brains of Aspa $a^{\text {Nur7/Nur7 }} / \mathrm{Nat}^{-1-}$ mice (data not shown).

Disrupting $\mathrm{Nat} 8 \mathrm{l}$ reduces the severity of motor dysfunction in Aspa $a^{\text {Nur7/Nur7 }}$ mice

We had previously reported that accelerating rotarod retention times of 2-month-old Aspa $a^{\mathrm{Nur} 7 / \mathrm{Nur} 7} / \mathrm{Nat}^{+l^{+/+}}$mice were shorter than those in 2-month-old wild-type $\left(\mathrm{Aspa}^{+/+} / \mathrm{Nat} \mathrm{I}^{+/+}\right)$mice, whereas retention times of 2-month-old $A s p a^{\text {Nur7/Nur7 }} / \mathrm{Nat}^{-1-} \mathrm{l}^{-1-}$ mice were not significantly different from those in wild-type mice (Guo et al. 2015). We retested these three groups of mice at age 1 year and obtained very similar results (Fig. $3 A$ ). We also tested Aspa $a^{\text {Nur7/Nur7 }} / \mathrm{Nat} \mathrm{l}^{+/-}$mice at 2 and 12 months of age and found their rotarod retention times to be intermediate between those of

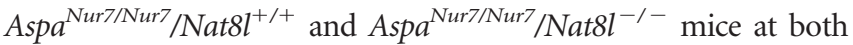
ages (Fig. $3 B$ ). We concluded that the protective effects of constitutive disruption of Nat8l on the rotarod performance of $A s p a^{\text {Nur7/Nur7 }}$ mice extend to at least 1 year of age.

\section{Disrupting Nat8l diminishes brain vacuolation in} Aspa $a^{\text {Nur7/Nur7 }}$ mice

As previously reported in brains of 2-month-old mice (Traka et al., 2008; Clarner et al., 2014; Guo et al., 2015; Maier et al., 2015),

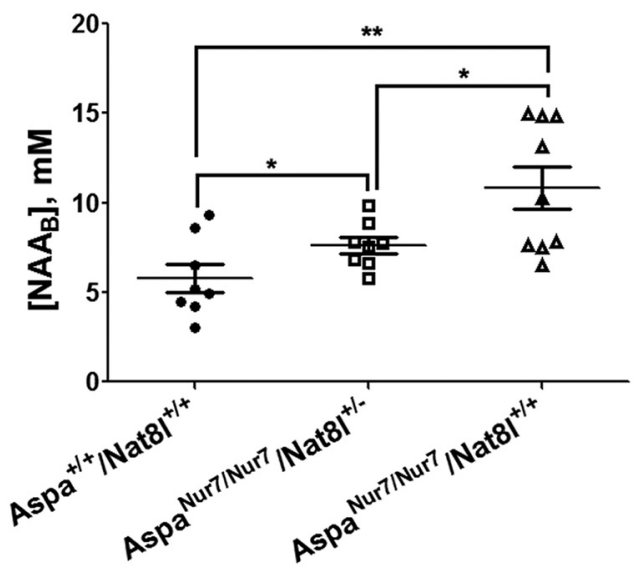

Figure 2. Nat8/ deletion lowers $\left[\mathrm{NAA}_{B}\right]$ in $A s p a^{\text {Nur7/Nur7 }}$ mice. $\left[\mathrm{NAA}_{\mathrm{B}}\right]$ in 6-month-old $A s p a^{\text {Nur7/Nur7 }}$ mice with one functional Nat8/ allele was intermediate between that in age-matched normal littermate control mice and in age-matched $A s p a^{\text {Nur7/Nur7 }}$ mice with two intact Nat8l alleles. Assays were done by HPLC. Each symbol represents a single mouse. Long horizontal bars indicate means, and vertical bars indicate SEMs. NAA was not detectable by HPLC in the brains of 6-month-old Aspa ${ }^{+/+} / \mathrm{Nat}^{-/-}$or

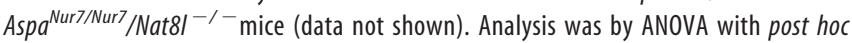
Tukey's multiple comparison test. ${ }^{*} p<0.05 ;{ }^{* *} p<0.01$.

cerebellar white matter and neighboring gray matter were vacuolated, immunoreactive MBP expression was diminished, and immunoreactive GFAP expression was increased in 6-month-old Aspa $a^{\text {Nur7/Nur7 }} / \mathrm{Nat}^{+1 /+}$ mice (Fig. 4). Deletion of both Nat8l alleles prevented this vacuolation and also prevented loss of immunoreactive MBP and induction of immunoreactive GFAP. Deletion of a single Nat $8 \mathrm{l}$ allele also diminished vacuolation but did not prevent loss of immunoreactive MBP or induction of immunoreactive GFAP (Fig. 4). Forebrain vacuolation in the 6-month-old Aspa $a^{\text {Nur7/Nur7 }}$ mice was also prevented by homozygous deletion of Nat8l (data not shown).

Transmission electron microscopy showed vacuoles and astroglial process swelling in the Purkinje cell layer of 1-year-old Aspa $a^{\text {Nur7/Nur7 }} / \mathrm{Nat} \mathrm{I}^{+/+}$mice. Vacuolation and astroglial swelling were less prominent in 1-year-old $A s p a^{\text {Nur7/Nur7 }} / \mathrm{Nat} \mathrm{I}^{+/-}$mice. Purkinje cell perikaryal morphology appeared normal in 1-yearold Aspa $a^{\text {Nur7/Nur7 }} / \mathrm{Nat} \mathrm{l}^{+/+}$and Aspa $a^{\mathrm{Nur} / \mathrm{Nur} 7} / \mathrm{Nat}^{+/-}$mice (Fig. 5).

\section{Nat81 deletion prevents loss of cerebral cortical NeuN ${ }^{+}$ neurons and progressive cerebral cortical thinning in Aspa ${ }^{\text {Nur7/Nur7 }}$ mice}

The number of $\mathrm{NeuN}^{+}$neurons per unit area in somatosensory cortex of $\mathrm{Aspa}^{+/+} / \mathrm{Nat} \mathrm{I}^{+/+}$mice was significantly greater than in 


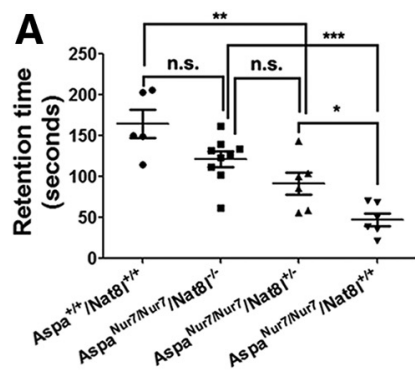

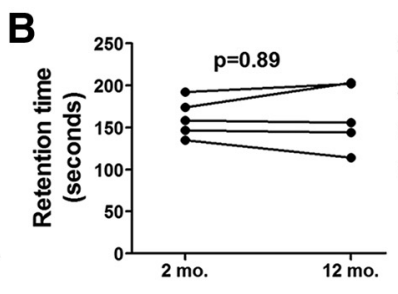

Aspa $^{+/+} / \mathrm{Nat}^{+/++}$

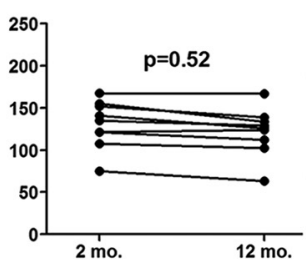

Aspa $^{\text {Nur7/Nur7/Nat81 } / \text { - }}$

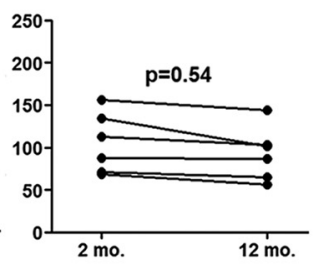

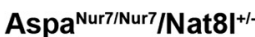

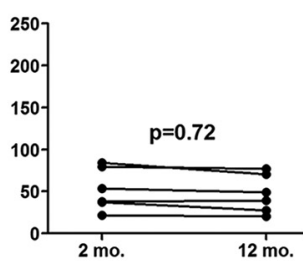

Aspa $^{\text {Nur7/Nur7/Nat8I }}{ }^{+++}$

Figure 3. Nat8/ deletion preserves motor function in $A s p a^{\text {Nur7/Nur7 }}$ mice. $A$, Mice were subjected to accelerating rotarod testing at 12 months of age. Each symbol represents a single mouse. Long horizontal bars indicate means, and vertical bars indicate SEMs. Analysis was by ANOVA with post hoc Tukey's multiple comparison test. ${ }^{*} p<0.05$; ${ }^{* *} p<0.01$; ${ }^{* * *} p<0.001 . B$, Accelerating rotarod retention time results in individual mice at 2 and 12 months of age are compared, with analysis within each of the four groups by Student's $t$ test. The 2 month data for $\mathrm{Aspa}^{+/+} / \mathrm{Nat} \mathrm{I}^{+/+}$,

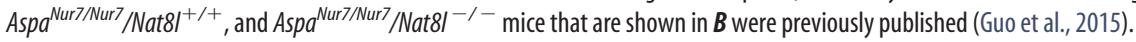
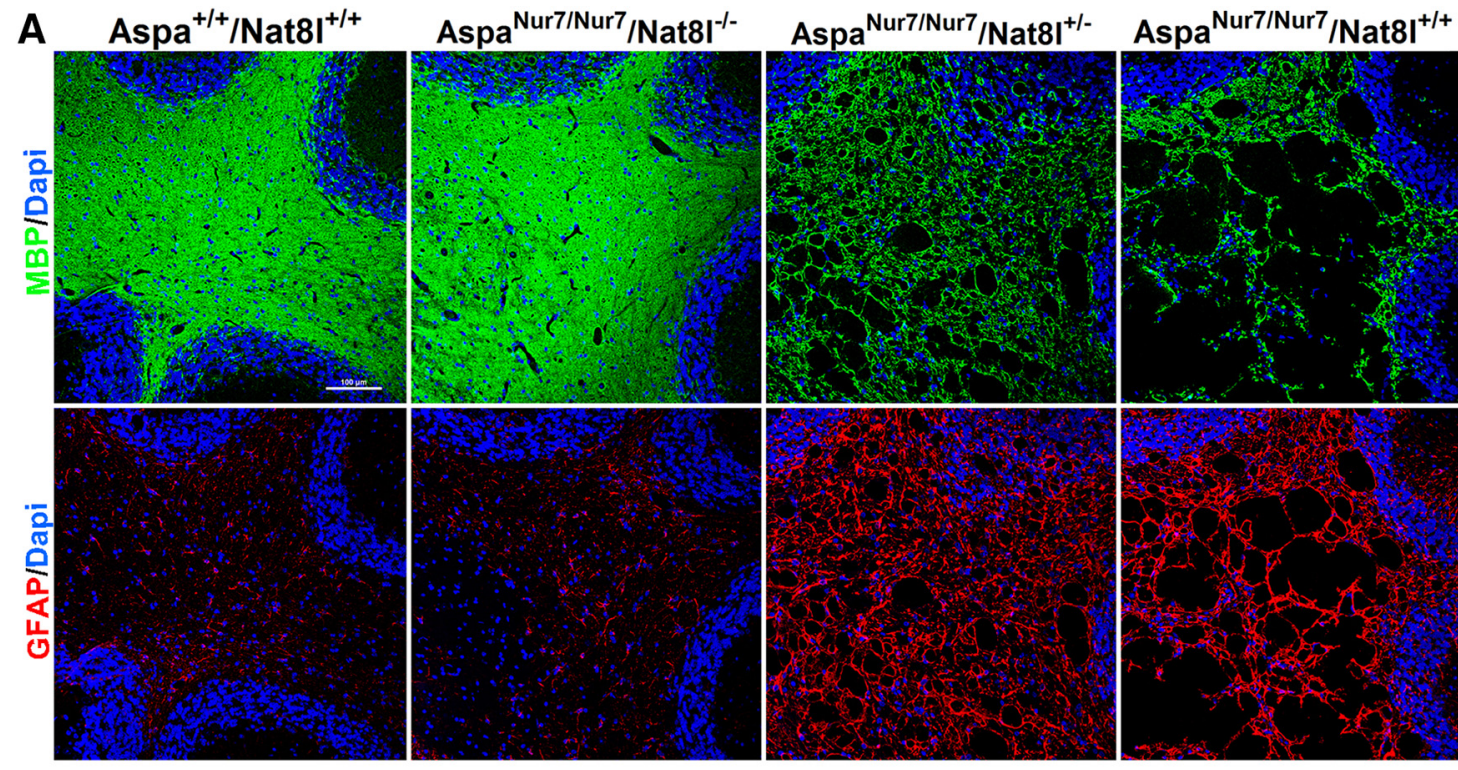

B

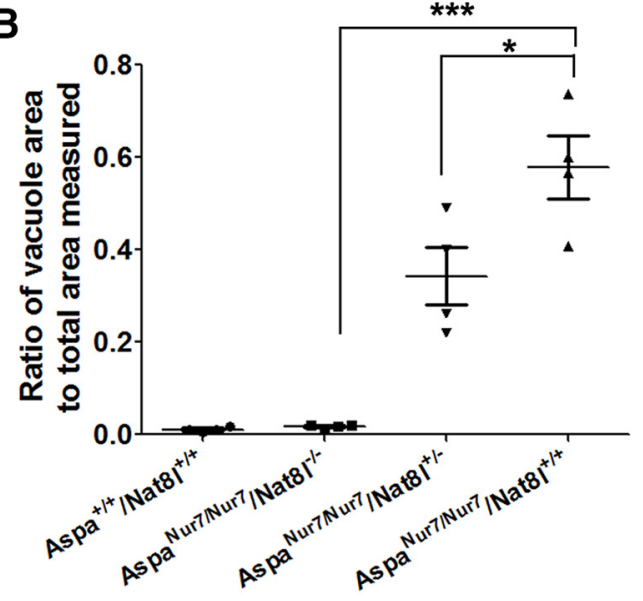

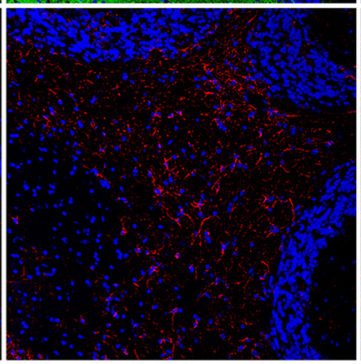
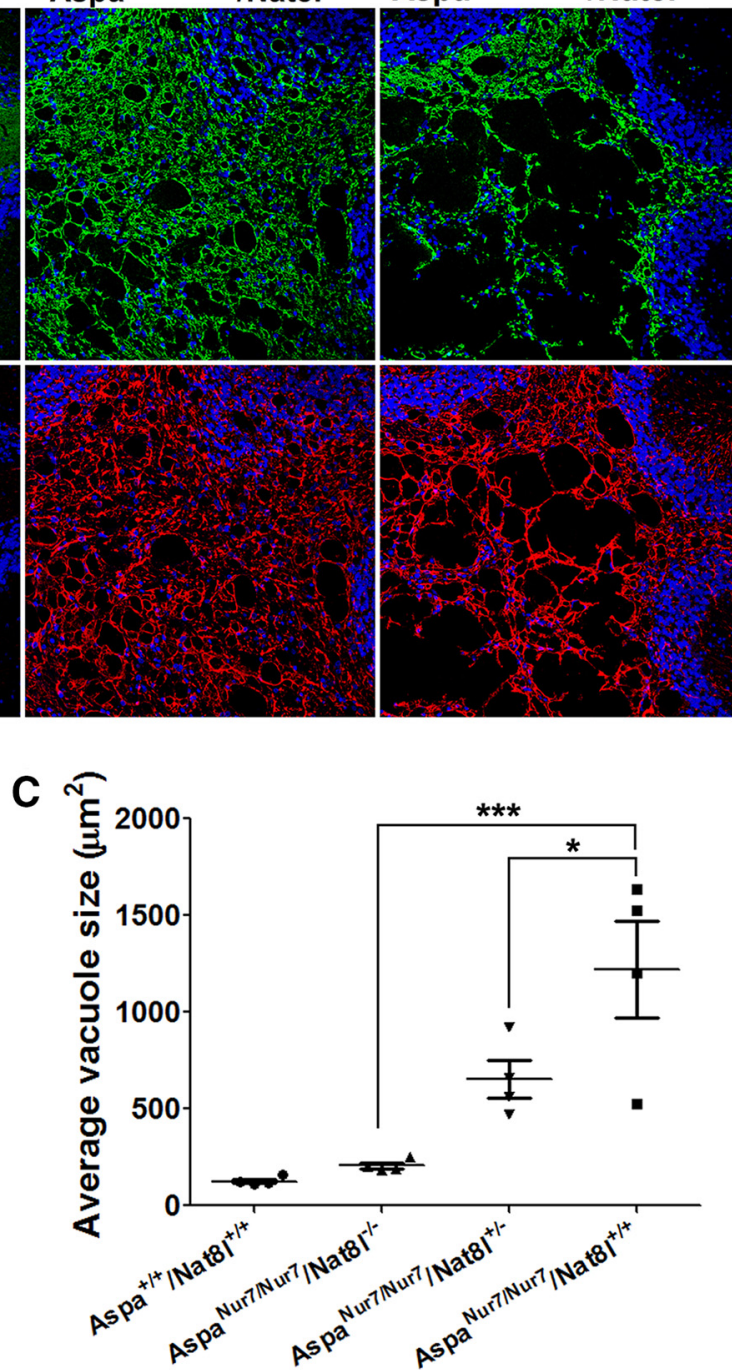

Figure 4. Nat8/ deletion diminishes cerebellar vacuolation in Aspa $a^{\text {Nur7/Nur7 }}$ mice. $A$, Representative low-power microscopic views (scale bar, $100 \mu \mathrm{m}$ ) immunostained for MBP (green, top) or GFAP (red, bottom) of 6-month-old mice of the genotypes indicated above the photos. Neuronal nuclei were counterstained with DAPI. $\boldsymbol{B}, \boldsymbol{C}$, Ratio of vacuole area to total area measured ( $\boldsymbol{B}$ ) and mean cerebellar vacuole size $(\boldsymbol{C})$ in 6-month-old mice of the indicated genotypes. Each symbol represents an individual mouse. Long horizontal bars indicate means, and vertical bars indicate SEMs. ${ }^{*} p<0.05 ;{ }^{* * *} p<0.001$.

Aspa $a^{\text {Nur7/Nur7 }} / \mathrm{Nat}^{+/+} \mathrm{l}^{++}$mice at both 2 and 12 months of age. Somatosensory cortical thickness in $\mathrm{Aspa}^{\mathrm{Nur} / \mathrm{Nur} 7} / \mathrm{Nat}^{+/ /+}$mice was slightly diminished at age 2 months and more substantially diminished at age 12 months compared with $\mathrm{Aspa}^{+/+} / \mathrm{Nat}^{+/+}$ mice (Fig. 6). Somatosensory cortical thickness and $\mathrm{NeuN}^{+}$neuron density in 12-month-old Aspa $a^{\mathrm{Nur} 7 / \mathrm{Nur} 7} / \mathrm{Nat}^{-1-} \mathrm{l}^{-1-}$ mice were not significantly different than in $\mathrm{Aspa}^{+/+} / \mathrm{Nat} \mathrm{I}^{+/+}$mice. Constitutive deletion of a single $\mathrm{Nat} 8 \mathrm{l}$ allele resulted in lesser protec- 

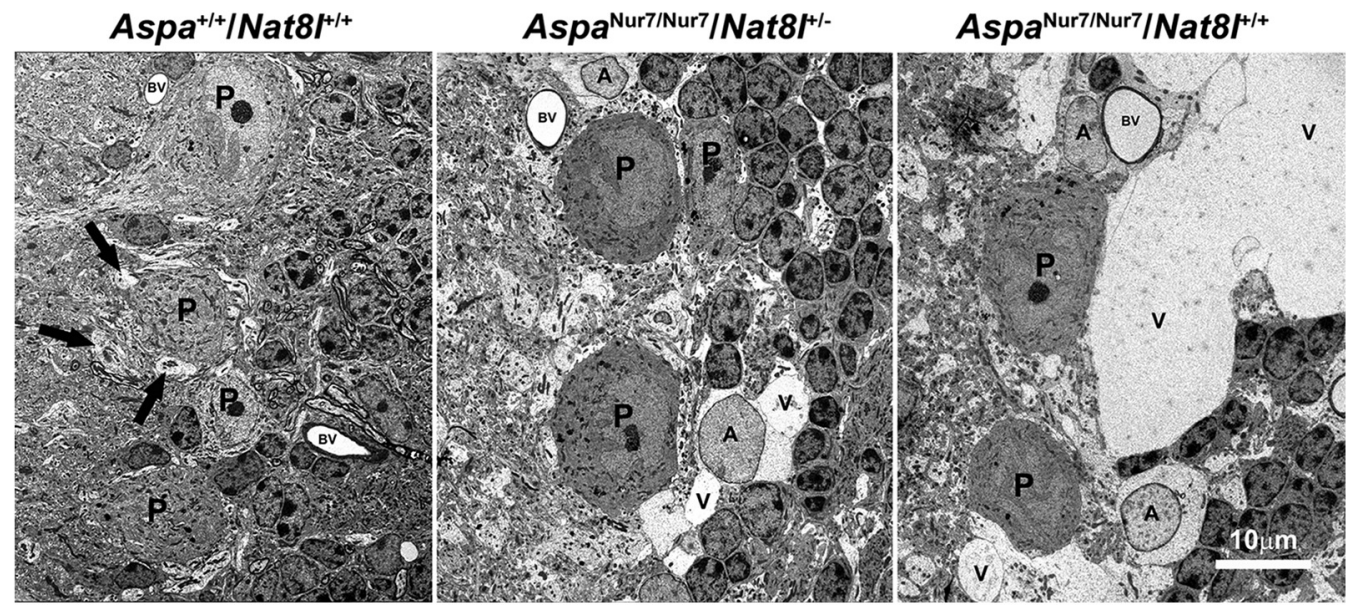

Figure 5. Nat8/ deletion diminishes vacuolation and astroglial swelling in the Purkinje cell layer of $A s p a^{\text {Nur7/Nur7 }}$ mice. Vacuoles (V) and nuclei of astroglia (A) with swollen processes are evident

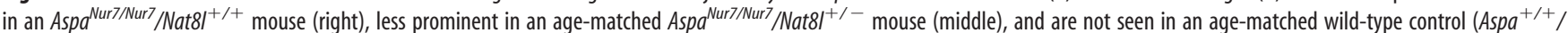
$\mathrm{Nat8l}^{+/+}$) mouse (left). Results are representative of those in three mice of each of these three genotypes. P, Purkinje cell nucleus; BV, blood vessel. Arrows in normal control (left) point to normal-sized astroglial processes. Scale bar, $10 \mu \mathrm{m}$.

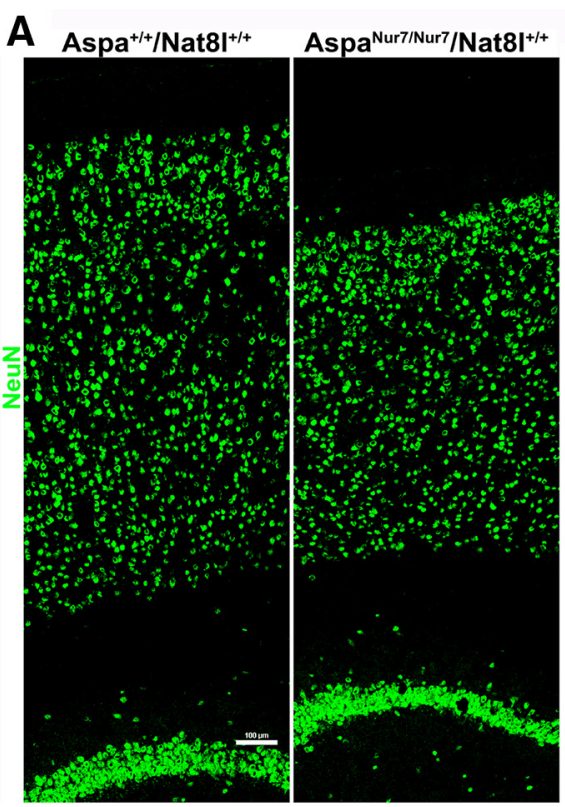

C
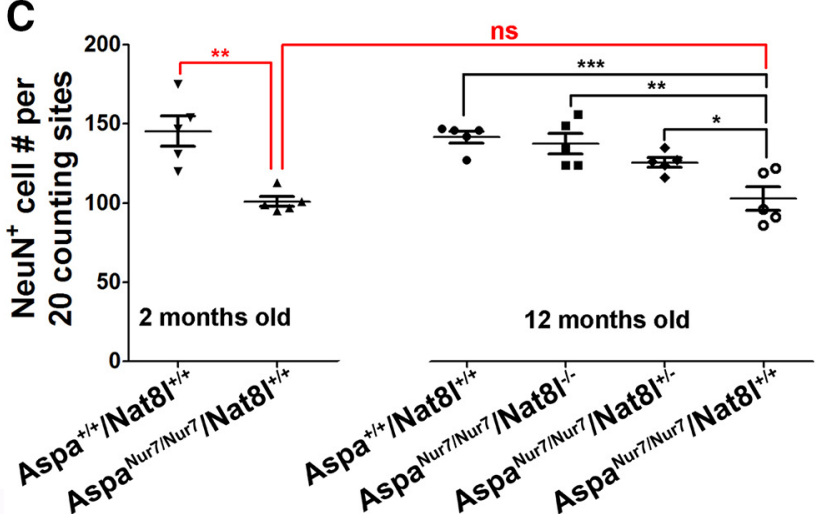
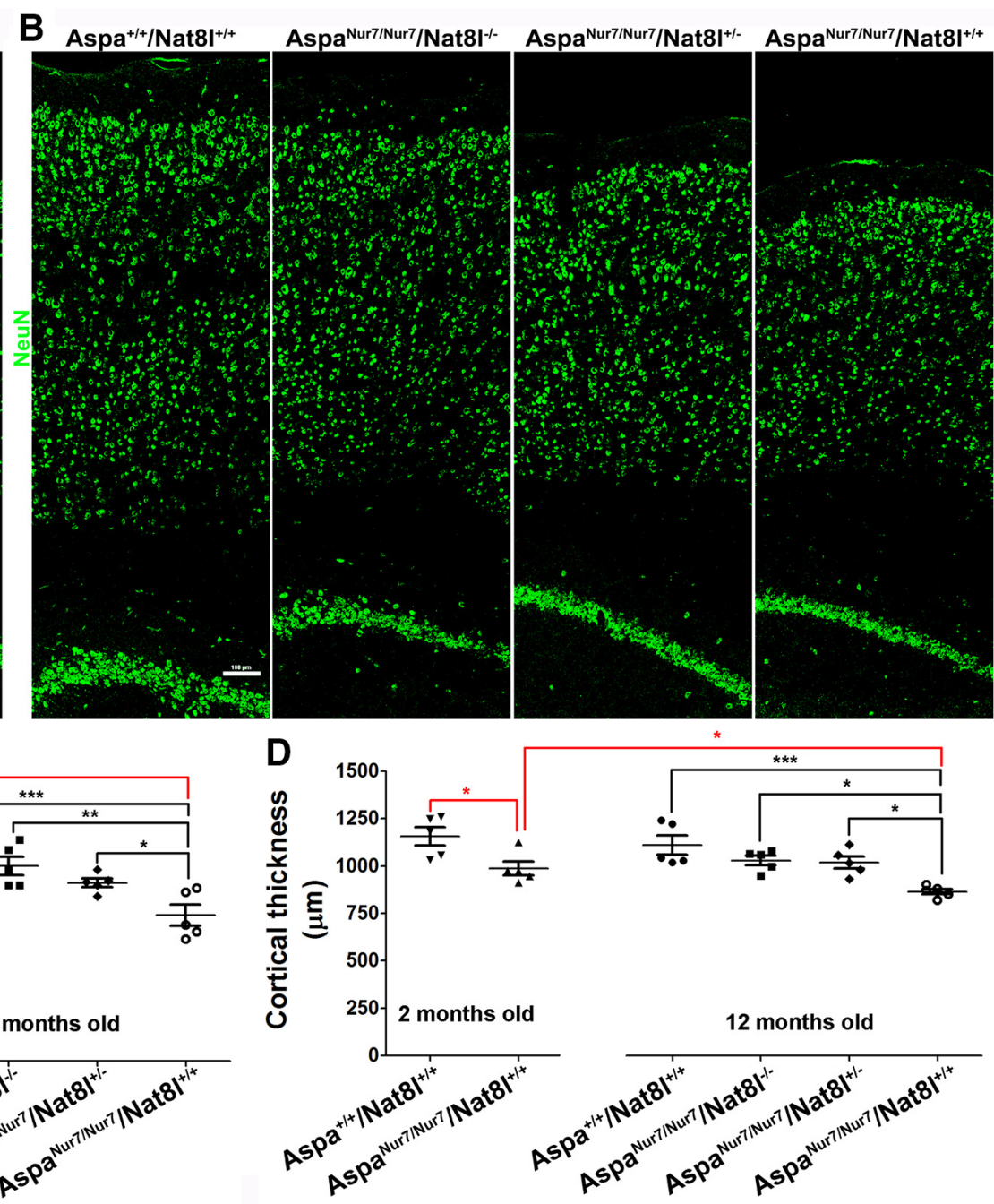

Figure 6. Nat8/ deletion diminishes cerebral cortical thinning and neuron loss in AspaNur7/Nur7 mice. In $\boldsymbol{A}$ and $\boldsymbol{B}$, neurons were immunostained for NeuN (scale bar, $100 \mu \mathrm{m}) . \boldsymbol{A}$, Somatosensory cortex in a representative 2-month-old Aspa ${ }^{+/+} / \mathrm{Nat} \mathrm{I}^{+/+}$mouse (left) and a representative 2-month-old Aspa ${ }^{\mathrm{Nur} / \mathrm{Nur}} / \mathrm{Nat8I^{+/+ }}$ mouse (right). $\boldsymbol{B}$, Somatosensory cortex in representative

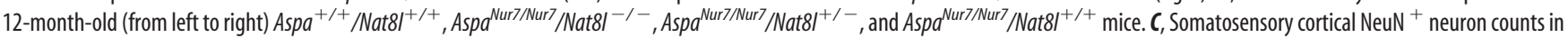
2- and 12-month-old mice. D, Somatosensory cortical thickness in 2- and 12-month-old mice. Each dot in C and $\boldsymbol{D}$ represents a single mouse. Vertical bars denote SEMs. Statistical analyses were by ANOVA with Tukey's multiple comparison test. ns, Not significantly different. ${ }^{*} p<0.05 ;{ }^{* *} p<0.01{ }^{* * *} p<0.001$. 


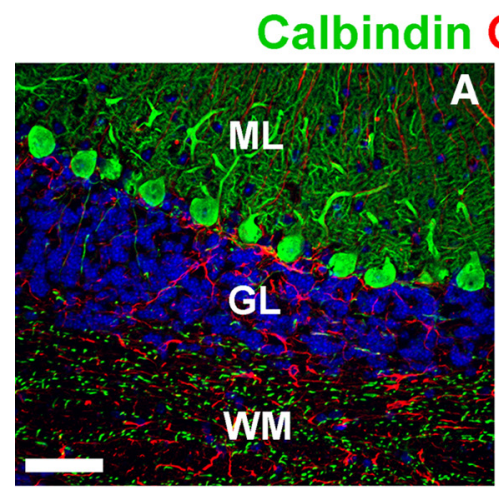

\section{GFAP DAPI}
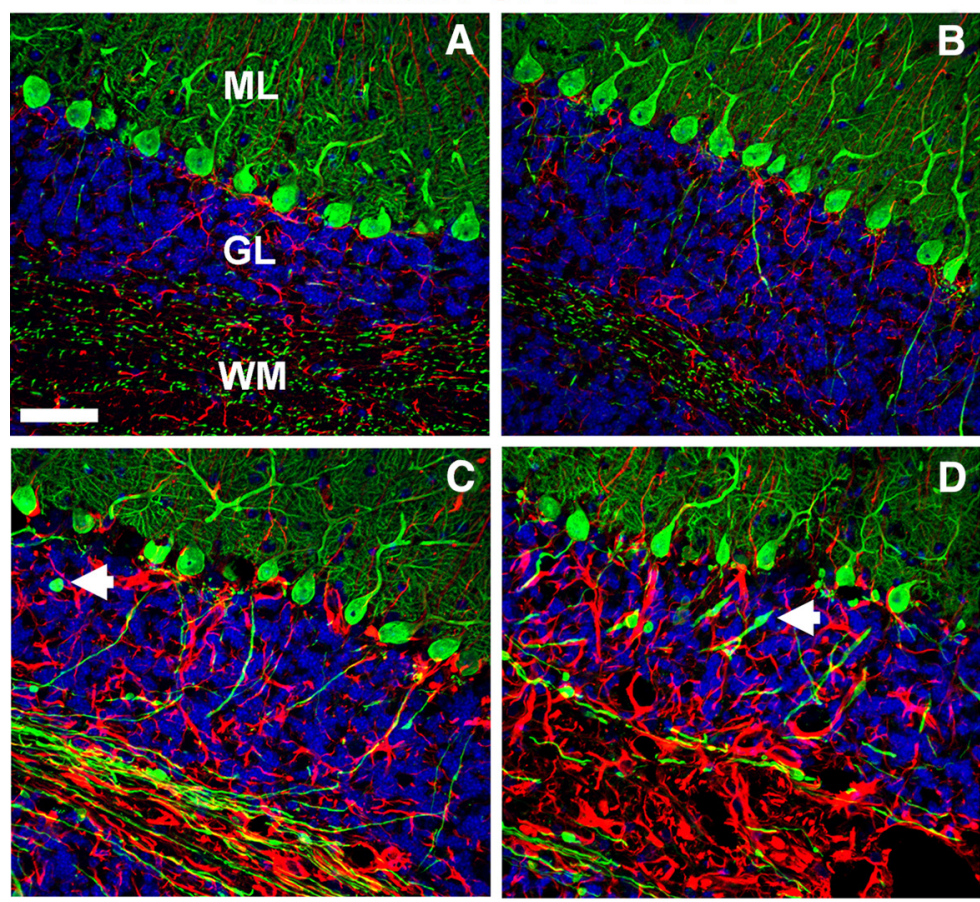
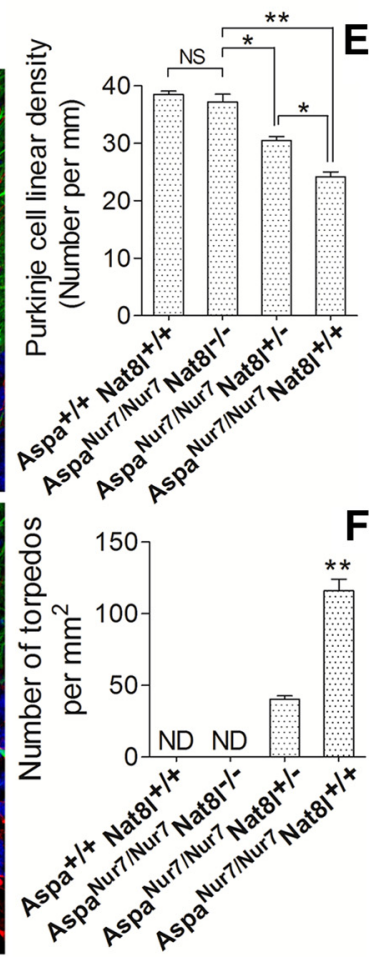

Figure 7. Nat8/ deletion preserves cerebellar Purkinje neurons in $A s p a^{\text {Nur7/Nur7 }}$ mice. $A-D$, The cerebellar molecular layer (ML), granule cell layer (GL), and white matter (WM) of representative

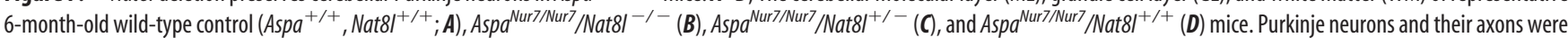
immunostained with a calbindin antibody. The sections were also immunostained for GFAP. Note the prominent GFAP induction and expansion of cerebellar white matter in the Aspa $a^{\text {Nur7/Nur7/ }}$ $\mathrm{Nat8l}^{+/+}$mouse. Nuclei were labeled with DAPI. Segmental Purkinje axonal dilatations ("torpedoes") are indicated by white arrows in ( and D. Scale bar, $50 \mu \mathrm{m}$. E, Comparison of Purkinje neuron linear densities in wild-type control mice versus in age-matched Aspa $a^{\text {Nur } / N \text { ur7 }}$ mice in which zero, one, or two Nat8/ alleles have been deleted. $\boldsymbol{F}$, Comparison of the frequency of Purkinje axonal dilatations in the various genotypes. $n=3$ mice in each group. Vertical bars denote SEMs. ${ }^{*} p<0.05 ;{ }^{* *} p<0.01$. ND, Not detected.

tive effects against cerebral cortical atrophy and neuron loss in 12-month-old Aspa $a^{\text {Nur7/Nur7 }}$ mice (Fig. 6).

\section{Nat8l deletion prevents loss of Purkinje and internal granule cell neurons in Aspa ${ }^{\text {Nur7/Nur7 }}$ mice}

Compared with 6-month-old wild-type $\left(A s p a^{+/+} / \mathrm{Nat} \mathrm{I}^{+/+}\right)$ mice, the numbers of calbindin ${ }^{+}$Purkinje neurons were significantly diminished in age-matched $A s p a^{\text {Nur } 7 / N u r 7} / \mathrm{Nat} \mathrm{I}^{+/+}$mice. The loss of Purkinje neurons was less marked in age-matched Aspa $a^{\text {Nur7/Nur7 }} / \mathrm{Nat}^{+1 /-}$ mice and was not detected in agematched Aspa $a^{\text {Nur7/Nur7 }} / \mathrm{Nat}^{-1 /-}$ mice (Fig. 7). The axons of some Purkinje neurons in $A s p a^{\text {Nur7/Nur7 }} / \mathrm{Nat}^{+/+} l^{++}$mice showed segmental swellings ("axonal torpedoes"; Babij et al., 2013), which resembled those reported in children with Canavan disease (Kamoshita et al., 1967; Jellinger and Seitelberger, 1969). Purkinje cell axon swellings were less frequent in 6-month-old Aspa $a^{\text {Nur7/Nur7 }} / \mathrm{Nat}^{+1 /-}$ mice and were not seen in 6-month-old Aspa $a^{\mathrm{Nur7} / \mathrm{Nur7}} / \mathrm{Nat}^{-1-} \mathrm{l}^{-/-}$or $\mathrm{Aspa}^{+/+} / \mathrm{Nat}^{+1 /+}$ mice (Fig. 7).

The area occupied by $\mathrm{NeuN}^{+}$cerebellar internal granule cells was smaller in 6-month-old Aspa $a^{\text {Nur7/Nur7 }} / \mathrm{Nat} \mathrm{I}^{+/+}$mice than in 6-month-old wild-type $\left(A s p a^{+/+} / \mathrm{Nat} \mathrm{I}^{+/+}\right)$mice; this diminution was less marked in 6-month-old $\mathrm{Aspa}^{\mathrm{Nur7} / \mathrm{Nur7}} / \mathrm{Nat}^{\mathrm{I}} \mathrm{I}^{+/-}$ mice, and no diminution was detected in 6-month-old Aspa $a^{\text {Nur7/Nur7 }} / \mathrm{Nat}^{-1-} \mathrm{l}^{-1-}$ mice (Fig. 8). Some internal granule cells in the 6-month-old Aspa $a^{\text {Nur7/Nur7 }} / \mathrm{Nat}^{+/+}$mice expressed cleaved caspase-3, suggesting ongoing apoptosis (Hurtado de Mendoza et al., 2011). The frequency of these $\mathrm{NeuN}^{+} /$cleaved caspase- $3^{+}$internal granule neurons was diminished in 6-month-old Aspa $a^{\text {Nur7/Nur7 }} / \mathrm{Nat}^{+l^{+/-}}$mice and was further reduced in $A s p a^{\text {Nur7/Nur7 }} / \mathrm{Nat}^{-/-}$mice (Fig. 8).

\section{Discussion}

Magnetic resonance imaging in Canavan disease demonstrates brain dysmyelination and progressive brain atrophy, and magnetic resonance spectroscopy shows markedly elevated $\left[\mathrm{NAA}_{\mathrm{B}}\right]$ (Janson et al., 2006b; Leone et al., 2012). The most prominent neuropathological findings are vacuolation, dysmyelination, and astrogliosis in brain superficial white matter and adjacent gray matter, but brain neuron loss has also been noted (Jellinger and Seitelberger, 1969; Adachi et al., 1973; Mirimanoff, 1976) and may contribute to progression of neurological deficits.

Aspa $a^{\text {Nur7/Nur7 }}$ mice express no immunochemically detectable Aspa, demonstrate markedly elevated $\left[\mathrm{NAA}_{\mathrm{B}}\right]$, and develop brain vacuolar degeneration beginning $\sim 2$ weeks after birth. These mice, which are already ataxic when weaned, become progressively more tremulous thereafter (Traka et al., 2008) and often die prematurely (Maier et al., 2015), have already proven useful in demonstrating that genetic ablation of NAA synthesis prevents brain vacuolation (Guo et al., 2015; Maier et al., 2015). However, the neuron depletion and progressive brain atrophy that occur in Canavan disease have not thus far been reported to occur in these mice, nor in any other Aspa-deficient rodent Canavan model (Matalon et al., 2000; Klugmann et al., 2005; Traka et al., 2008; Mersmann et al., 2011; Clarner et al., 2014; Guo et al., 2015; Maier et al., 2015). Indeed, numbers of cerebellar internal granule cells were noted to be slightly increased in 14-d-old Aspa $a^{\text {Nur7/Nur7 }}$ mice (Traka et al., 2008), and another study reported numbers of $\mathrm{NeuN}^{+}$neurons in forebrains of 8 week postnatal Aspa $a^{\text {Nur7/Nur7 }}$ mice to be normal, although the cerebral cortical region sampled in that study was not specified (Francis et al., 2012). 

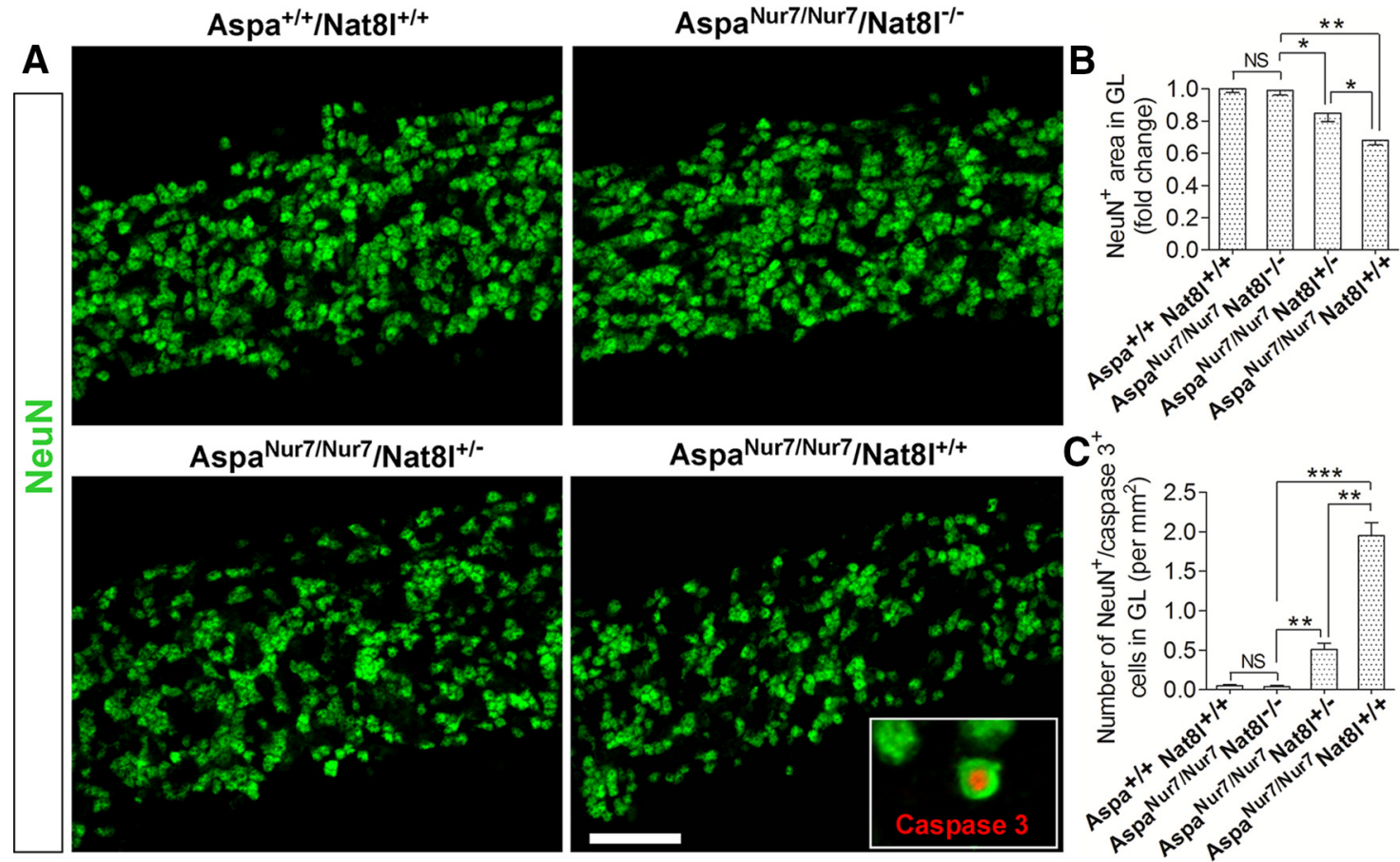

Figure 8. Nat8/ deletion preserves internal granule cell layer area and diminishes incidence of cleaved caspase- $3^{+}$granule cell neurons in Aspa $a^{\text {Nur } 7 / N u r 7}$ mice. $\boldsymbol{A}$, NeuN immunostaining of

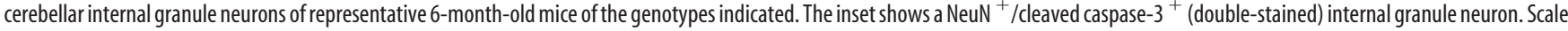
bar, $100 \mu \mathrm{m}$. B. Fold change in areas occupied by NeuN ${ }^{+}$internal granule neurons determined by NIH ImageJ and shown as means ( $n=3$ mice per group), with SEMs indicated by vertical bars. C, Numbers of NeuN ${ }^{+} /$cleaved caspase- $3^{+}$neurons $/ \mathrm{mm}^{2}$ in the internal granule cell layer. ${ }^{*} p<0.05 ;{ }^{* *} p<0.01 ;{ }^{* * *} p<0.001$. NS, Not significantly different.

We have now documented decreased $\mathrm{NeuN}^{+}$neuron density and mild thinning of somatosensory cortex at age 2 months and substantially more severe cortical thinning by age 12 months in Aspa $a^{\text {Nur7/Nur7 }}$ mice. Also, in cerebellum, numbers of cerebellar Purkinje and internal granule neurons are diminished by age 6 months. These losses of cerebral cortical and cerebellar neurons are prevented by homozygous constitutive Nat8l deletion and partially prevented by heterozygous constitutive $\mathrm{Nat} 8 \mathrm{l}$ deletion.

NAA has three known functions in brain: as an obligatory precursor for the neuromodulator $\mathrm{N}$-acetyl-L-aspartyl-Lglutamate (NAAG; Pouwels and Frahm, 1997; Neale et al., 2011); as an intermediate in the transfer of acetate from neurons to oligodendroglia, where acetyl carbons can be converted to acetylCoA and incorporated into myelin lipids (Burri et al., 1991; Madhavarao et al., 2005; Moffett et al., 2013; Prokesch et al., 2016); and as an osmolyte that astroglia use to assist in maintaining CNS osmolar/water homeostasis (Fujita et al., 2005; Yodoya et al., 2006; Baslow and Guilfoyle, 2013). It has been hypothesized that the elevated $\left[\mathrm{NAA}_{\mathrm{B}}\right]$ in Canavan disease perturbs the astroglial osmolar regulatory mechanism, thus leading to astroglial swelling and myelin intraperiod line splitting (Baslow and Guilfoyle, 2013; Clarner et al., 2014). This hypothesis was supported by the demonstration that genetic ablation of NAA synthesis prevents vacuolation and dysmyelination in $A s p a^{N u r 7 / N u r 7}$ mice (Guo et al., 2015; Maier et al., 2015).

How might elevated $\left[\mathrm{NAA}_{\mathrm{B}}\right]$ cause neuron loss? Neurons might be injured by a direct toxic effect of NAA and/or NAAG. NAAG, although elevated in Canavan brain (Mochel et al., 2010), was not toxic for internal granule cells in cerebellar slices (Kolodziejczyk et al., 2009), but intracerebroventricular NAA caused cerebral cortical oxidative injury (Pederzolli et al., 2009) and killed hippocampal neurons (Pliss et al., 2003). Alternatively, high $\left[\mathrm{NAA}_{\mathrm{B}}\right]$ may have a secondary effect on neuronal viability by causing axonal dysmyelination (Traka et al., 2008) and/or by impairing other neuronotrophic effects of oligodendroglia and astroglia (Furuya et al., 2000; Wilkins et al., 2003; Morrison et al., 2013; Machler et al., 2016; Verkhratsky and Nedergaard, 2016).

Would interventions to diminish $\left[\mathrm{NAA}_{\mathrm{B}}\right]$ be safe for infants and children with Canavan disease? There is as yet no proof that the modest decreases in $\left[\mathrm{NAA}_{\mathrm{B}}\right]$ seen in neuroinflammatory/ neurodegenerative brain disorders as a consequence of brain mitochondrial dysfunction are themselves deleterious, although they may cause changes in CNS myelin lipid composition (Ciccarelli et al., 2010; Li et al., 2013; Singhal et al., 2016). However, obliteration of NAA synthesis by inactivation of both Nat8l alleles, although not causing dysmyelination or obvious motor deficits in $\mathrm{Nat}^{-1-} \mathrm{I}^{-1-}$ mice (Guo et al., 2015), has been associated with subtle behavioral abnormalities (Furukawa-Hibi et al., 2012; Toriumi et al., 2015), and the one known human with documented homozygous NAT8L deletion was developmentally delayed, ataxic, and microcephalic (Martin et al., 2001; Wiame et al., 2009). Homozygous inactivation of Slc25a12, which encodes the brain mitochondrial aspartate-glutamate carrier, also profoundly diminishes $\left[\mathrm{NAA}_{\mathrm{B}}\right]$ and causes developmental delay and hypomyelination (Wibom et al., 2009; Sakurai et al., 2010), but lack of NAA might not be responsible for this phenotype since Slc25a12 knock-out also disrupts lactate utilization by neurons and perhaps also by oligodendroglia (Rinholm and Bergersen, 2014; Llorente-Folch et al., 2016).

In conclusion, we have demonstrated that preventing [ $\left.\mathrm{NAA}_{\mathrm{B}}\right]$ from becoming markedly elevated can mitigate loss of cerebral cortical and cerebellar neurons and progressive cerebral cortical thinning in Aspa-deficient mice. Measures to suppress brain NAA overload, either by inhibiting NAA synthesis or by acceler- 
ating brain NAA clearance, may also enhance neuronal survival in infants and children with Canavan disease.

\section{References}

Adachi M, Schneck L, Cara J, Volk BW (1973) Spongy degeneration of the central nervous system (van Bogaert and Bertrand type; Canavan's disease). A review. Hum Pathol 4:331-347. CrossRef Medline

Ariyannur PS, Moffett JR, Manickam P, Pattabiraman N, Arun P, Nitta A, Nabeshima T, Madhavarao CN, Namboodiri AM (2010) Methamphetamine-induced neuronal protein NAT8L is the NAA biosynthetic enzyme: implications for specialized acetyl coenzyme A metabolism in the CNS. Brain Res 1335:1-13. CrossRef Medline

Babij R, Lee M, Cortés E, Vonsattel JP, Faust PL, Louis ED (2013) Purkinje cell axonal anatomy: quantifying morphometric changes in essential tremor versus control brains. Brain 136:3051-3061. CrossRef Medline

Bakken TE, Miller JA, Ding SL, Sunkin SM, Smith KA, Ng L, Szafer A, Dalley RA, Royall JJ, Lemon T, Shapouri S, Aiona K, Arnold J, Bennett JL, Bertagnolli D, Bickley K, Boe A, Brouner K, Butler S, Byrnes E, et al. (2016) A comprehensive transcriptional map of primate brain development. Nature 535:367-375. CrossRef Medline

Baslow MH, Guilfoyle DN (2013) Canavan disease, a rare early-onset human spongiform leukodystrophy: insights into its genesis and possible clinical interventions. Biochimie 95:946-956. CrossRef Medline

Burri R, Steffen C, Herschkowitz N (1991) N-Acetyl-L-aspartate is a major source of acetyl groups for lipid synthesis during rat brain development. Dev Neurosci 13:403-411. CrossRef Medline

Chakraborty G, Mekala P, Yahya D, Wu G, Ledeen RW (2001) Intraneuronal $\mathrm{N}$-acetylaspartate supplies acetyl groups for myelin lipid synthesis: evidence for myelin-associated aspartoacylase. J Neurochem 78:736-745. CrossRef Medline

Ciccarelli O, Toosy AT, De Stefano N, Wheeler-Kingshott CA, Miller DH, Thompson AJ (2010) Assessing neuronal metabolism in vivo by modeling imaging measures. J Neurosci 30:15030-15033. CrossRef Medline

Clarner T, Wieczorek N, Krauspe B, Jansen K, Beyer C, Kipp M (2014) Astroglial redistribution of aquaporin 4 during spongy degeneration in a Canavan disease mouse model. J Mol Neurosci 53:22-30. CrossRef Medline

Feigenbaum A, Moore R, Clarke J, Hewson S, Chitayat D, Ray PN, Stockley TL (2004) Canavan disease: carrier-frequency determination in the Ashkenazi Jewish population and development of a novel molecular diagnostic assay. Am J Med Genet 124A:142-147. CrossRef Medline

Francis JS, Strande L, Pu A, Leone P (2011) Endogenous aspartoacylase expression is responsive to glutamatergic activation in vitro and in vivo. Glia 59:1435-1446. CrossRef Medline

Francis JS, Strande L, Markov V, Leone P (2012) Aspartoacylase supports oxidative metabolism during myelination. J Cereb Blood Flow Metab 32:1725-1736. CrossRef Medline

Francis JS, Wojtas I, Markov V, Gray SJ, McCown TJ, Samulski RJ, Bilaniuk LT, Wang DJ, De Vivo DC, Janson CG, Leone P (2016) N-acetylaspartate supports the energetic demands of developmental myelination via oligodendroglial aspartoacylase. Neurobiol Dis 96:323-334. CrossRef Medline

Fujita T, Katsukawa H, Yodoya E, Wada M, Shimada A, Okada N, Yamamoto A, Ganapathy V (2005) Transport characteristics of N-acetyl-Laspartate in rat astrocytes: involvement of sodium-coupled high-affinity carboxylate transporter $\mathrm{NaC} 3 / \mathrm{NaDC} 3$-mediated transport system. J Neurochem 93:706-714. CrossRef Medline

Furukawa-Hibi Y, Nitta A, Fukumitsu H, Somiya H, Toriumi K, Furukawa S, Nabeshima T, Yamada K (2012) Absence of SHATI/Nat8l reduces social interaction in mice. Neurosci Lett 526:79-84. CrossRef Medline

Furuya S, Tabata T, Mitoma J, Yamada K, Yamasaki M, Makino A, Yamamoto T, Watanabe M, Kano M, Hirabayashi Y (2000) L-Serine and glycine serve as major astroglia-derived trophic factors for cerebellar Purkinje neurons. Proc Natl Acad Sci U S A 97:11528-11533. CrossRef Medline

Gambetti P, Mellman WJ, Gonatas NK (1969) Familial spongy degeneration of the central nervous system (Van Bogaert-Bertrand disease). An ultrastructural study. Acta Neuropathol (Berl) 12:103-115. CrossRef Medline

Giannaris EL, Rosene DL (2012) A stereological study of the numbers of neurons and glia in the primary visual cortex across the lifespan of male and female rhesus monkeys. J Comp Neurol 520:3492-3508. CrossRef Medline
Guo F, Bannerman P, Mills Ko E, Miers L, Xu J, Burns T, Li S, Freeman E, McDonough JA, Pleasure D (2015) Ablating N-acetylaspartate prevents leukodystrophy in a Canavan disease model. Ann Neurol 77:884-888. CrossRef Medline

Hurtado de Mendoza T, Perez-Garcia CG, Kroll TT, Hoong NH, O’Leary DD, Verma IM (2011) Antiapoptotic protein Lifeguard is required for survival and maintenance of Purkinje and granular cells. Proc Natl Acad Sci U S A 108:17189-17194. CrossRef Medline

Janson CG, Kolodny EH, Zeng BJ, Raghavan S, Pastores G, Torres P, Assadi M, McPhee S, Goldfarb O, Saslow B, Freese A, Wang DJ, Bilaniuk L, Shera D, Leone P (2006a) Mild-onset presentation of Canavan's disease associated with novel G212A point mutation in aspartoacylase gene. Ann Neurol 59:426-431. CrossRef Medline

Janson CG, McPhee SW, Francis J, Shera D, Assadi M, Freese A, Hurh P, Haselgrove J, Wang DJ, Bilaniuk L, Leone P (2006b) Natural history of Canavan disease revealed by proton magnetic resonance spectroscopy $\left({ }^{1} \mathrm{H}-\mathrm{MRS}\right)$ and diffusion-weighted MRI. Neuropediatrics 37:209-221. CrossRef Medline

Jellinger K, Seitelberger F (1969) Juvenile form of spongy degeneration of the CNS. Acta Neuropathol (Berl) 13:276-281. CrossRef Medline

Jolly S, Fudge A, Pringle N, Richardson WD, Li H (2016) Combining double fluorescence in situ hybridization with immunolabelling for detection of the expression of three genes in mouse brain sections. J Vis Exp 109: e53976. CrossRef Medline

Kamoshita S, Reed GB Jr, Aguilar MJ (1967) Axonal dystrophy in a case of Canavan's spongy degeneration. Neurology 17:895-898. CrossRef Medline

Kaul R, Gao GP, Aloya M, Balamurugan K, Petrosky A, Michals K, Matalon R (1994) Canavan disease: mutations among Jewish and non-Jewish patients. Am J Hum Genet 55:34-41. Medline

Klugmann M, Leichtlein CB, Symes CW, Serikawa T, Young D, During M) (2005) Restoration of aspartoacylase activity in CNS neurons does not ameliorate motor deficits and demyelination in a model of Canavan disease. Mol Ther 11:745-753. CrossRef Medline

Kolodziejczyk K, Hamilton NB, Wade A, KáradóttirR, Attwell D (2009) The effect of $\mathrm{N}$-acetyl-aspartyl-glutamate and $\mathrm{N}$-acetyl-aspartate on white matter oligodendrocytes. Brain 132:1496-1508. CrossRef Medline

Leone P, Shera D, McPhee SW, Francis JS, Kolodny EH, Bilaniuk LT, Wang DJ, Assadi M, Goldfarb O, Goldman HW, Freese A, Young D, During MJ, Samulski RJ, Janson CG (2012) Long-term follow-up after gene therapy for Canavan disease. Sci Transl Med 4:165ra163. CrossRef Medline

Li S, Clements R, Sulak M, Gregory R, Freeman E, McDonough J (2013) Decreased NAA in gray matter is correlated with decreased availability of acetate in white matter in postmortem multiple sclerosis cortex. Neurochem Res 38:2385-2396. CrossRef Medline

Llorente-Folch I, Rueda CB, Pérez-Liébana I, SatrústeguiJ, Pardo B (2016) L-Lactate-mediated neuroprotection against glutamate-induced excitotoxicity requires ARALAR/AGC1. J Neurosci 36:4443-4456. CrossRef Medline

Machler P, Wyss MT, Elsayed M, Stobart J, Gutierrez R, von Faber-Castell A, Kaelin V, Zuend M, San Martín A, Romero-Gómez I, Baeza-Lehnert F, Lengacher S, Schneider BL, Aebischer P, Magistretti PJ, Barros LF, Weber B (2016) In vivo evidence for a lactate gradient from astrocytes to neurons. Cell Metab 23:94-102. CrossRef Medline

Madhavarao CN, Arun P, Moffett JR, Szucs S, Surendran S, Matalon R, Garbern J, Hristova D, Johnson A, Jiang W, Namboodiri MA (2005) Defective $\mathrm{N}$-acetylaspartate catabolism reduces brain acetate levels and myelin lipid synthesis in Canavan's disease. Proc Natl Acad Sci U S A 102:52215226. CrossRef Medline

Maier H, Wang-Eckhardt L, Hartmann D, Gieselmann V, Eckhardt M (2015) N-Acetylaspartate synthase deficiency corrects the myelin phenotype in a Canavan disease mouse model but does not affect survival time. J Neurosci 35:14501-14516. CrossRef Medline

Martin E, Capone A, Schneider J, Hennig J, Thiel T (2001) Absence of $\mathrm{N}$-acetylaspartate in the human brain: impact on neurospectroscopy? Ann Neurol 49:518-521. CrossRef Medline

Matalon R, Rady PL, Platt KA, Skinner HB, Quast MJ, Campbell GA, Matalon K, Ceci JD, Tyring SK, Nehls M, Surendran S, Wei J, Ezell EL, Szucs S (2000) Knock-out mouse for Canavan disease: a model for gene transfer to the central nervous system. J Gene Med 2:165-175. CrossRef Medline Mersmann N, Tkachev D, Jelinek R, Röth PT, Möbius W, Ruhwedel T, Rühle S, Weber-Fahr W, Sartorius A, Klugmann M (2011) Aspartoacylase- 
lacZ knockin mice: an engineered model of Canavan disease. PLoS One 6:e20336. CrossRef Medline

Mirimanoff P (1976) La dystrophie spongieuse hereditaire des enfants (Canavan:Van Bogaert-Pertrand). J Neurol Sci 28:159-185. CrossRef Medline

Mochel F, Boildieu N, Barritault J, Sarret C, Eymard-Pierre E, Seguin F, Schiffmann R, Boespflug-Tanguy O (2010) Elevated CSF N-acetylaspartylglutamate suggests specific molecular diagnostic abnormalities in patients with white matter diseases. Biochim Biophys Acta 1802:11121117. CrossRef Medline

Moffett JR, Arun P, Ariyannur PS, Namboodiri AM (2013) N-Acetylaspartate reductions in brain injury: impact on post-injury neuroenergetics, lipid synthesis, and protein acetylation. Front Neuroenergetics 5:11. CrossRef Medline

Morrison BM, Lee Y, Rothstein JD (2013) Oligodendroglia: metabolic supporters of axons. Trends Cell Biol 23:644-651. CrossRef Medline

Neale JH, Olszewski RT, Zuo D, Janczura KJ, Profaci CP, Lavin KM, Madore JC, Bzdega T (2011) Advances in understanding the peptide neurotransmitter NAAG and appearance of a new member of the NAAG neuropeptide family. J Neurochem 118:490-498. CrossRef Medline

Pederzolli CD, Rockenbach FJ, Zanin FR, Henn NT, Romagna EC, Sgaravatti AM, Wyse AT, Wannmacher CM, Wajner M, de Mattos Dutra A, DutraFilho CS (2009) Intracerebroventricular administration of N-acetylaspartic acid impairs antioxidant defenses and promotes protein oxidation in cerebral cortex of rats. Metab Brain Dis 24:283-298. CrossRef Medline

Pinol MR, Kägi U, Heizmann CW, Vogel B, Séquier JM, Haas W, Hunziker W (1990) Poly- and monoclonal antibodies against recombinant rat brain calbindin D-28K were produced to map its selective distribution in the central nervous system. J Neurochem 54:1827-1833. CrossRef Medline

Pliss L, Balcar VJ, Bubeníková V, Pokorný J, Fitzgibbon T, St'astný F (2003) Morphology and ultrastructure of rat hippocampal formation after I.C.V. administration of N-acetyl-L-aspartyl-L-glutamate. Neuroscience 122: 93-101. CrossRef Medline

Pouwels PJ, Frahm J (1997) Differential distribution of NAA and NAAG in human brain as determined by quantitative localized proton MRS. NMR Biomed 10:73-78. CrossRef Medline

Prokesch A, Pelzmann HJ, Pessentheiner AR, Huber K, MadreiterSokolowski CT, Drougard A, Schittmayer M, Kolb D, Magnes C, Trausinger G, Graier WF, Birner-Gruenberger R, Pospisilik JA, Bogner-Strauss JG (2016) N-acetylaspartate catabolism determines cytosolic acetylCoA levels and histone acetylation in brown adipocytes. Sci Rep 6:23723. CrossRef Medline

Rattray I, Smith E, Gale R, Matsumoto K, Bates GP, Modo M (2013) Correlations of behavioral deficits with brain pathology assessed through longitudinal MRI and histopathology in the R6/2 mouse model of HD. PLoS One 8:e60012. CrossRef Medline

Rinholm JE, Bergersen LH (2014) White matter lactate-does it matter? Neuroscience 276:109-116. CrossRef Medline

Sakurai T, Ramoz N, Barreto M, Gazdoiu M, Takahashi N, Gertner M, Dorr N, Gama Sosa MA, De Gasperi R, Perez G, Schmeidler J, Mitropoulou V, Le HC, Lupu M, Hof PR, Elder GA, Buxbaum JD (2010) Slc25a12 disruption alters myelination and neurofilaments: a model for a hypomyelination syndrome and childhood neurodevelopmental disorders. Biol Psychiatry 67:887-894. CrossRef Medline

Sarnat HB, Nochlin D, Born DE (1998) Neuronal nuclear antigen (NeuN): a marker of neuronal maturation in the early human fetal nervous system. Brain Dev 20:88-94. CrossRef Medline

Shaag A, Anikster Y, Christensen E, Glustein JZ, Fois A, Michelakakis H, Nigro F, Pronicka E, Ribes A, Zabot MT (1995) The molecular basis of Canavan (aspartoacylase deficiency) disease in European non-Jewish patients. Am J Hum Genet 57:572-580. Medline

Singhal NK, Huang H, Li S, Clements R, Gadd J, Daniels A, Kooijman EE, Bannerman P, Burns T, Guo F, Pleasure D, Freeman E, Shriver L, McDonough J (2016) The neuronal metabolite NAA regulates histone H3 methylation in oligodendrocytes and myelin lipid composition. Exp Brain Res. Advance online publication. Retrieved October 5, 2016. doi: 10.1007/s00221-016-4789-z. CrossRef Medline

Toriumi K, Mamiya T, Song Z, Honjo T, Watanabe H, Tanaka J, Kondo M, Mouri A, Kim HC, Nitta A, Fukushima T, Nabeshima T (2015) Deletion of SHATI/NAT8L decreases the N-acetylaspartate content in the brain and induces behavioral deficits, which can be ameliorated by administering N-acetylaspartate. Eur Neuropsychopharmacol 25:2108-2117. CrossRef Medline

Traeger EC, Rapin I (1998) The clinical course of Canavan disease. Pediatr Neurol 18:207-212. CrossRef Medline

Traka M, Wollmann RL, Cerda SR, Dugas J, Barres BA, Popko B (2008) Nur7 is a nonsense mutation in the mouse aspartoacylase gene that causes spongy degeneration of the CNS. J Neurosci 28:11537-11549. CrossRef Medline

Valenzuela DM, Murphy AJ, Frendewey D, Gale NW, Economides AN, Auerbach W, Poueymirou WT, Adams NC, Rojas J, Yasenchak J, Chernomorsky R, Boucher M, Elsasser AL, Esau L, Zheng J, Griffiths JA, Wang X, Su H, Xue Y, Dominguez MG, et al.(2003) High-throughput engineering of the mouse genome coupled with high-resolution expression analysis. Nat Biotech 21:652-659. CrossRef Medline

Verkhratsky A, Nedergaard M (2016) The homeostatic astroglia emerges from evolutionary specialization of neural cells. Philos Trans R Soc Lond B Biol Sci 371:pii:20150428. CrossRef Medline

Wang Q, Zhao M, Parungao GG, Viola RE (2016) Purification and characterization of aspartate $\mathrm{N}$-acetyltransferase: a critical enzyme in brain metabolism. Protein Expr Purif 119:11-18. CrossRef Medline

Wiame E, Tyteca D, Pierrot N, Collard F, Amyere M, Noel G, Desmedt J, Nassogne MC, Vikkula M, Octave JN, Vincent MF, Courtoy PJ, Boltshauser E, van Schaftingen E (2009) Molecular identification of aspartate $\mathrm{N}$-acetyltransferase and its mutation in hypacetylaspartia. Biochem J 425:127-136. CrossRef Medline

Wibom R, Lasorsa FM, Töhönen V, Barbaro M, Sterky FH, Kucinski T, Naess K, Jonsson M, Pierri CL, Palmieri F, Wedell A (2009) AGC1 deficiency associated with global cerebral hypomyelination. N Engl J Med 361: 489-495. CrossRef Medline

Wilkins A, Majed H, Layfield R, Compston A, Chandran S (2003) Oligodendrocytes promote neuronal survival and axonal length by distinct intracellular mechanisms: a novel role for oligodendrocyte-derived glial cell line-derived neurotrophic factor. J Neurosci 23:4967-4974. Medline

Yodoya E, Wada M, Shimada A, Katsukawa H, Okada N, Yamamoto A, Ganapathy V, Fujita T (2006) Functional and molecular identification of sodium-coupled dicarboxylate transporters in rat primary culture cerebrocortical astrocytes and neurons. J Neurochem 97:162-173. CrossRef Medline 